\title{
STUDI KUALITAS BAKTERIOLOGIS AIR MINUM ISI ULANG PADA DEPOT AIR MINUM ISI ULANG DI WILAYAH KERJA PUSKESMAS 1 PURWOKERTO TIMUR KABUPATEN BANYUMAS TAHUN 2018
}

\author{
Aldi Gilang Mahfedika' ${ }^{1)}$, Zaeni Budiono ${ }^{2)}$ \\ Jurusan Kesehatan Lingkungan, Politeknik Kesehatan Kemenkes Semarang, \\ Jl. Raya Baturraden KM 12 Purwokerto, Indonesia
}

\begin{abstract}
Abstrak
Depot air minum merupakan usaha industri yang melakukan proses pengolahan air baku menjadi air minum dan menjual langsung kepada konsumen. Keberadaan DAMIU terus meningkat sejalan dengan kebutuhan masyarakat terhadap air minum yang bermutu dan aman untuk dikonsumsi. Meski lebih murah tidak semua DAMIU terjamin keamanan produknya. Adanya bakteri coliform pada air minum yang melebihi standar maksimum berdasarkan Permenkes No. 492 tahun 2010 tentang persyaratan kualitas air minum dapat menyebabkan berbagai jenis penyakit. Tujuan penelitian ini untuk mengetahui kualitas bakteriologis air minum isi ulang pada DAMIU di wilayah kerja Puskesmas 1 Purwokerto Timur. Metode penelitian yang digunakan adalah deskriptif. Hasil penelitian menunjukan bahwa dari 9 DAMIU 6 DAMIU memenuhi syarat dan 3 DAMIU tidak memenuhi syarat higiene sanitasi DAMIU. Hasil Pemeriksaan Laboratorium terdapat 6 DAMIU memenuhi syarat dan 3 DAMIU yang tidak memenuhi persyaratan bakteriologis air minum sesuai Permenkes NO 492 tahun 2010 tentang persyaratan kualitas air minum. Kesimpulan dari hasil penelitian ini adalah dari 9 DAMIU yang diteliti 6 DAMIU memenuhi syarat dan 3 DAMIU tidak memenuhi syarat kualitas bakteriologis air minum. Disarankan bagi pemilik atau pengelola DAMIU sebaiknya mengganti lampu UV yang pemakaiannya sudah melebihi 9.000 jam dan kapasitas UV disesuaikan dengan debit air yang digunakan untuk proses pengolahan agar air minum yang dihasilkan memenuhi syarat kualitas bakteriologis air minum.
\end{abstract}

Kata Kunci : Coliform; Air Minum Isi Ulang; Kesehatan Lingkungan

\begin{abstract}
QUALITY STUDY OF BACTERIOLOGICAL DRINKING WATER REFILL STATION IN THE REGION OF EAST PUBLIC HEALTH DISTRICT OF BANYUMAS YEAR 2018. Drinking water depots are industrial businesses that process raw water into drinking water and sell directly to consumers. The existence of DAMIU continues to increase in line with people's need for quality drinking water and safe for consumption. Although cheaper not all DAMIU guaranteed product security. The existence of microbiology ie Coliform bacteria in drinking water that exceeds the maximum standard based on Permenkes no. 492 of 2010 on drinking water quality regulations can cause various types of diseases. The purpose of this research is to know the bacteriological quality of drinking water refill at DAMIU in the working area of Puskesmas 1 East Purwokerto. The research method used is descriptive. The results of DAMIU hygiene sanitation assessment obtained 6 DAMIU eligible and 3 DAMIU not qualified. The result of laboratory examination there are 6 eligible DAMIU and 3 DAMIU which do not meet the bacteriological regulations of drinking water pursuant to Permenkes no 492/2010 on drinking water quality regulations. The conclusion of this research is from 9 DAMIU studied 6 DAMIU qualified and 3 DAMIU not qualified bacteriological quality of drinking water. Suggestions that can be given that should the owner or manager DAMIU should always replace the UV lamps whose usage has exceeded 9000 hours and adjust the flow of water out of the processing equipment with UV capacity for processed water results meet the regulations of bacteriological quality.
\end{abstract}

Keywords $\quad$ : Colifrom; Drinking Water Refill; Environmental Health 


\section{Pendahuluan}

Sehat merupakan kondisi optimal fisik, mental dan sosial seseorang sehingga dapat memiliki prodktivitas, bukan hanya terhindar dari penyakit. Manusia harus mempunyai kesadaran, kemampuan, kemauan untuk hidup sehat sehingga akan terwujud derajat kesehatan yang optimal. Untuk mewujudkan derajat kesehatan yang optimal salah satu upaya yang dilakukan adalah pemenuhan air minum yang sehat (Depkes RI, 1999).

Air minum adalah air yang dapat diminum langsung atau air yang harus dimasak terlebih dahulu sebelum dapat diminum. (Depkes RI, 2010). Kebutuhan tubuh terhadap air minum dibutuhkan sebanyak $3 \%$ dari berat badan atau sekitar 2.3 liter per hari. Air minum dalam tubuh manusia berguna untuk menjaga keseimbangan metabolisme dan fisiologi tubuh.

Sebagian besar kebutuhan air minum masyarakat selama ini dipenuhi dari air sumur, mata air, air sungai, air danau dan juga air yang sudah diolah oleh perusahaan air minum daerah (PDAM). Semakin sibuknya aktivitas manusia maka masyarakat cenderung memilih cara yang lebih praktis dengan biaya yang relatif lebih murah untuk memenuhi kebutuhan air minum yaitu dengan menggunakan air minum isi ulang (Pracoyo, 2006).

Menurut Athena (2004) yang mengutip dari Siswanto (2003), masyarakat saat ini mulai beralih pada air minum isi ulang yang berasal dari depot. Air minum ini lebih dikenal dengan air minum isi ulang karena masyarakat memperoleh air minum ini dengan cara mengisi galon yang dibawanya di depot air minum. Keberadaan depot air minum isi ulang terus meningkat sejalan dengan dinamika keperluan masyarakat terhadap air minum yang bermutu dan aman untuk dikonsumsi. Meskipun pada kenyaataann depot air minum isi ulang terjamin keamanan produknya.

Setiap penyelenggara air minum wajib menjamin air minum yang diproduksinya aman bagi kesehatan (DEPKES RI, 2010). Air minum yang dihasilkan oleh depot air minum harus memenuhi persyaratan kesehatan sesuai dengan Peraturan Menteri Kesehatan Republik Indonesia Nomor 492/MENKES/Per/VI/2010 tentang persyaratan kualitas air minum.
1) E-mail
: aldigilang1206@gmail.com
2) E-mail
:pakzaeni@gmail.com

Air minum yang memenuhi syarat dapat dilihat dari unsur biologis, kimia, fisika, dan radioaktif. Secara umum indikator bakteriologis air minum tidak boleh mengandung bakteri Coliform.

Tujuan penelitian ini adalah mengetahui kualitas bakteriologis air minum pada Depot Air Minum Isi Ulang (DAMIU) di wilayah kerja Puskesmas 1 Purwokerto Timur Kabupaten Banyumas.

\section{Bahan dan Metode}

Design penelitian ini adalah observasional yang dimaksudkan untuk mendapatkan data faktual tentang kualitas bakteriologis air minum isi ulang (DAMIU) di wilayah kerja Puskesmas 1 Purwokerto Timur Kabupaten Banyumas. Subyek dalam penelitian ini adalah depot air minum isi ulang yang berada di wilayah kerja Puskesmas 1 Purwokerto Timur, yaitu sebanyak 9 Depot Air Minum Isi Ulang.

Jenis data penelitian adalah data umum dan data khusus. Data umum diperoleh peneliti berasal dari laporan atau catatan yang dimiliki tempat penelitian (DAMIU) dilaksanakan seperti nama DAMIU, penanggung jawab DAMIU, alamat DAMIU, sertifikat izin laik higiene sanitasi DAMIU, lama penggunaan dan jumlah tenaga kerja. Data khusus yang dikumpulkan adalah data sumber air baku yang digunakan untuk pengolahan air minum pada DAMIU, jenis pengolahan air minum yang digunakan pada DAMIU, kondisi higiene sanitasi DAMIU dan kualitas bakteri Coliform pada air sesudah melalui proses pengolahan pada DAMIU yang berada di wilayah kerja Puskesmas 1 Purwokerto Timur.

Sumber data penelitian ini adalah data primer dan data sekunder. Data primer diperoleh dari DAMIU yang berada diwilayah kerja Puskesmas 1 Purwokerto Timur. Data sekunder diperoleh dari Puskesmas 1 Purwokerto Timur, penanggung jawab DAMIU dan Laboratorium Kesehatan Masyarakat Kabupaten Banyumas. Pengumpulan data dilakukan dengan cara observasi, wawancara dan pengukuran. Instrument yang digunakan berupa checklist.

Pengolahan Data yang dilakukan dengan cara editing (pengolahan) yaitu mencatat, mengkoreksi, dan menyeleksi data DAMIU yang diperoleh dari wawancara, observasi, pemeriksaan sampel dan data dari pihak yang terkait. Pengkodean (coding) yaitu pemberian kode pada data hasil pengamatandan pengukuran yang diperoleh di lapangan. Pengelompokan/ klasifikasi data. Penyimpanan (saving) yaitu menyimpan data-data hasil pengukuran yang akan digunakan untuk penelitian. Tabulasi data (tabulating) yaitu pengolahan data kedalam bentuk table untuk dianalisis. Pemeriksaan 
(cleaning) yaitu memastikan bahwa data yang telah diperoleh benar dan bebas dari kesalahan.

Analisis data yang digunakan dalam penelitian ini adalah analisis deskriptif yaitu menggunakan tabel dan narasi, yang meliputi mengetahui sumber air baku yang digunakan DAMIU, mendeskripsikan pengolahan DAMIU dan kondisi sanitasi DAMIU, mendeskripsikan perilaku tenaga kerja pada DAMIU dan menghitung bakteri Coliform kemudian membandingkan dengan: Permenkes RI No. 492/Menkes/Per/IV tahun 2010 tentang Persyaratan Kualitas Air Minum dan Permenkes RI No. 43 Tahun 2014 tentang Higiene Sanitasi Depot Air Minum Isi Ulang.

Etika penelitian yang digunakan meliputi informed consent (lembar persetujuan), lembar persetujuan peneliti dengan responden yang berisi tentang penjelasan penelitian yang akan dilakukan. Hal ini untuk meminta izin dan menghormati hak-hak. Anonymity, peneliti akan menjaga kerahasiaan responden maka peneliti tidak akan mencantumkan nama responden pada lembar pengumpulan data atau hasil penelitian yang akan disajikan. Confidentiality, kerahasiaan informasi yang diberikan oleh subyek dijamin oleh peneliti, hanya kelompok data tertentu yang akan dilaporkan sebagai hasil penelitian.

\section{Hasil dan Pembahasan}

Depot air minum merupakan usaha industri yang melakukan proses pengolahan air baku menjadi air minum dan menjual langsung kepada konsumen. Purwokerto Timur khususnya wilayah kerja Puskesmas 1 Purwokerto Timur merupakan daerah perkotaan padat penduduk yang memenuhi kebutuhan air minum salah satunya menggunakan air minum isi ulang. Berikut data DAMIU di wilayah kerja Puskesmas 1 Purwokerto Timur Kabupaten Banyumas Tahun 2018.

\section{A. Data Umum}

Tabel 1. Data Umum DAMIU

\begin{tabular}{cccc}
\hline NO. & Nama & $\begin{array}{c}\text { Penanggung } \\
\text { DawiU }\end{array}$ & $\begin{array}{c}\text { Tenaga } \\
\text { Kerja }\end{array}$ \\
\hline 1. & DAMIU A & YT & 3 \\
2. & DAMIU B & AS & 1 \\
3. & DAMIU C & SA & 1 \\
4. & DAMIU D & AG & 2 \\
5. & DAMIU E & An & 1 \\
6. & DAMIU F & NW & 1 \\
7. & DAMIU G & TF & 1 \\
8. & DAMIU H & MM & 1 \\
9. & DAMIU I & IS & 1 \\
\hline
\end{tabular}

Wilayah kerja Puskesmas 1 Purwokerto Timur berada di Kecamatan Purwokerto Timur Kabupaten Banyumas. Kecamatan Purwokerto Timur terdiri dari 6 kelurahan dan terbagi atas 2 wilayah yaitu Puskesmas 1 dan Puskesmas 2 Purwokerto Timur. Wilayah kerja Puskesmas 1 Purwokerto Timur meliputi 3 kelurahan yaitu Kelurahan Mersi, Kelurahan Arcawinangun, dan Kelurahan Purwokerto Wetan.

Puskesmas 1 Purwokerto Timur menaungi 9 DAMIU yang tersebar di 3 Kelurahan yaitu 5 DAMIU Kelurahan Purwokerto Wetan, 1 DAMIU Kelurahan Mersi, 3 DAMIU Kelurahan Arcawinangun.

Sertifikasi Izin Laik Higiene Sanitasi DAMIU Tabel 2. Sertifikasi Izin Laik Higienes Sanitasi DAMIU

\section{Sertifikasi Izin Laik Higiene Sanitasi DAMIU}

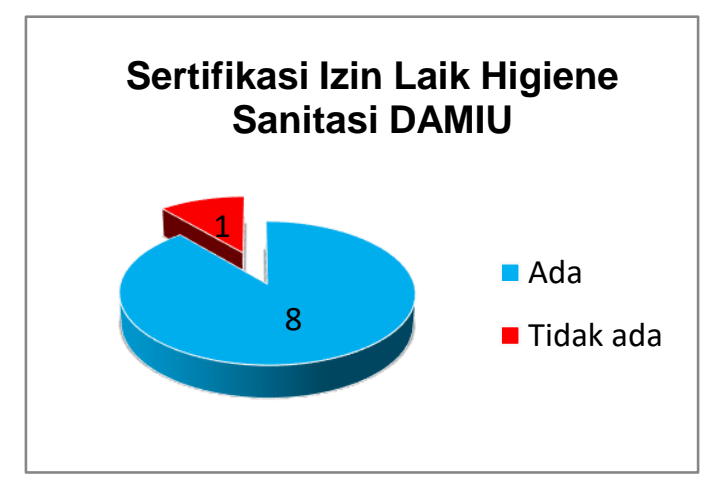

Sertifikat Laik Higiene Sanitasi adalah bukti tertulis yang dikeluarkan oleh Dinas Kesehatan Kabupaten/ Kota atau Kantor Kesehatan Pelabuhan yang menerangkan bahwa DAM telah memenuhi standar baku mutu atau persyaratan kualitas air minum dan persyaratan higiene sanitasi. Pelaksanaan perizinan pendirian usaha Depot Air Minum Isi Ulang di Kabupaten Banyumas yang dilaksanakan oleh Dinas Kesehatan Kabupaten Banyumas telah sesuai dengan pedoman pelaksanaan penyelenggaraan higiene sanitasi Depot Air Minum pada Peraturan Menteri Kesehatan Republik Indonesia No 43 Tahun 2014. Sertifikat Laik Higiene Sanitasi berlaku selama 3 (tiga) tahun dan dapat diperpanjang selama memenuhi persyaratan.

9 Depot Air Miunum Isi Ulang (DAMIU) yang diteliti di wilayah kerja Puskesmas 1 Purwokerto Timur Kabupaten Banyumas bahwa 8 depot air minum isi ulang yang memiliki laik higiene sanitasi yaitu pada depot air miunum isi ulang A, C, D, E, F, G, H, I sedangkan 1 depot air miunum isi ulang yang belum memiliki sertifikat laik Higiene Sanitasi yaitu pada depot air miunum isi ulang $\mathrm{B}$ dengan keterangan masih dalam proses atau sedang diurus. 


\section{B. Data Khusus}

Tabel 3. Sumber Air DAMIU

\begin{tabular}{cccc}
\hline No. & $\begin{array}{c}\text { Nama } \\
\text { DAMIU }\end{array}$ & $\begin{array}{c}\text { Sumber } \\
\text { Air }\end{array}$ & Ket \\
\hline 1. & DAMIU A & Sumur Gali & TMS \\
2. & DAMIU B & Sumur Bor & TMS \\
3. & DAMIU C & PDAM & MS \\
4. & DAMIU D & Sumur Bor & TMS \\
5. & DAMIU E & PDAM & MS \\
6. & DAMIU F & Sumur Bor & TMS \\
7. & DAMIU G & Sumur Gali & TMS \\
8. & DAMIU H & Sumur Gali & TMS \\
9. & DAMIU I & PDAM & MS \\
\hline
\end{tabular}

Berdasarkan hasil observasi yang diperoleh data dari 9 DAMIU yang ada di Wilayah Kerja Puskesmas 1 Purwokerto Timur Kabupaten Banyumas bahwa 3 DAMIU menggunakan sumber air baku dari sumur gali, 3 DAMIU menggunakan sumber air baku dari sumur bor, 3 DAMIU menggunakan sumber air baku dari PDAM.

Berdasarkan hasil perhitungan inspeksi sumber air baku bahwa sumber air baku dari sumur gali yang digunakan pada DAMIU A , DAMIU G dan DAMIU H tidak memenuhi syarat dengan kategori yaitu adanya jamban dalam jarak 10 meter sekitar sumur, adanya sumber pencemar lain seperti kotoran hewan, sampah dalam jarak 10 meter, adanya keretakan pada lantai sekitar sumur, sewaktu-waktu ada genangan air di atas lantai sekeliling sumur.

Data yang diperoleh hasil perhitungan inspeksi sumber air baku bahwa sumber air baku sumur bor yang digunakan pada DAMIU B, DAMIU D dan DAMIU F tidak memenuhi syarat dengan kategori adanya jamban dalam jarak 10 meter sekitar sumur, adanya genangan air, adanya sumber pencemar lain seperti kotoran hewan, sampah dalam jarak 10 meter. Sumur bor umumnya air tanah yang bebas dari pengkotor mikrobiologi dan secara langsung dapat dipergunakan sebagai air minum, bilamana sumur semacam ini beserta pompanya dibangun dengan bangunan yang terlindung.

Data hasil pemeriksaan kualitas air PDAM yang telah dilakukan Puskesmas bahwa sumber air baku PDAM yang digunakan DAMIU C, DAMIU E dan DAMIU H memenuhi syarat.
Tabel 4. Proses Pengolahan DAMIU

\begin{tabular}{ccc}
\hline No. & $\begin{array}{c}\text { Nama } \\
\text { DAMIU }\end{array}$ & $\begin{array}{c}\text { Jenis } \\
\text { Pengolahan }\end{array}$ \\
\hline 1. & DAMIU A & UV \\
2. & DAMIU B & UV \\
3. & DAMIU C & UV \\
4. & DAMIU D & UV \\
5. & DAMIU E & UV \\
6. & DAMIU F & UV \\
7. & DAMIU G & UV \\
8. & DAMIU H & UV \\
9. & DAMIU I & UV \\
\hline DAMIU & yang berada di wilayah kerja
\end{tabular}

Puskesmas 1 Purwokerto Timur dari 9 DAMIU yang diteliti proses pengolahan air baku menjadi air minum yaitu dengan menggunakan sinar Ultra Violet.

Tabel 5. Kondisi Sanitasi pada DAMIU

\begin{tabular}{cccc}
\hline No. & $\begin{array}{c}\text { Nama } \\
\text { DAMIU }\end{array}$ & $\begin{array}{c}\text { Hasil } \\
\text { Penilaian }\end{array}$ & Ket \\
\hline 1. & DAMIU A & 67 & TMS \\
2. & DAMIU B & 64 & TMS \\
3. & DAMIU C & 75 & MS \\
4. & DAMIU D & 76 & MS \\
5. & DAMIU E & 62 & TMS \\
6. & DAMIU F & 74 & MS \\
7. & DAMIU G & 74 & MS \\
8. & DAMIU H & 78 & MS \\
9. & DAMIU I & 72 & MS \\
\hline
\end{tabular}

\section{DAMIU A}

Kondisi lantai pada DAMIU A sudah kedap air, permukaan rata, tidak licin, mudah dibersihkan dan kemiringan lantai cukup landai. Keadaan dinding sudah kedap air, permukaan rata, tidak retak, serta memiliki warna yang terang dan cerah, sedangkan untuk langit-langit pada DAMIU A sudah cukup kuat, mudah dibersihkan, berwarna terang serta memiliki ketinggian yang cukup. Kondisi pencahayaan pada DAMIU A cukup terang untuk bekerja, tidak menyilaukan dan tersebar secara merata, sehingga pekerjaan tidak terganggu akibat pencahayaan yang kurang atau berlebih. Ventilasi pada DAMIU A sudah cukup memadai, sehingga pertukaran udara berjalan dengan lancar serta kelembaban udara yang dihasilkan dapat mendukung kenyamanan dalam meakukan pekerjaan/ aktivitas. DAMIU A sudah memiliki akses kamar mandi dan jamban bagi pekerja nya, sedangkan untuk saluran pembuangan air limbah belum tertutup. DAMIU A belum memiliki tempat sampah yang tertutup namun DAMIU A sudah memiliki tempat cuci tangan yang dilengkapi air dan sabun. Kondisi pada DAMIU A sudah bebas dari tikus, lalat dan kecoa. 
Mikrofilter dan peralatan desinfeksi masih dalam masa pakai/ tidak kadaluarsa, serta memiliki lebih dari satu mikro filter dengan ukuran berjenjang. DAMIU A sudah memiliki peralatan sterilisasi berupa ultra violet yang biasa digunakan untuk proses produksi. Penggunaan sinar ultra violet dilakukan pergantian jika lampu sudah mulai menyala redup, biasanya 1 tahun sekali, tergantung pada penggunaan ultra violet.

Penjamah/ operator pada DAMIU A dalam kondisi sehat, bebas penyakit menular, tidak menjadi pembawa kuman penyakit, menggunakan pakaian kerja yang bersih dan rapi serta penanggung jawab DAMIU A memiliki sertifikat pelatihan higiene sanitasi depot air minum dan belum adanya pemeriksaan kesehatan secara berkala untuk operator yang bekerja pada DAMIU A tersebut.

Bahan baku atau air baku yang digunakan belum memenuhi persyaratan fisik, mikrobiologi dan kimia standar serta kualitas air minum yang dihasilkan belum memenuhi persyaratan sesuai Permenkes RI Nomor 492/MENKES/Per/VI/2010 tentang persyaratan kualitas air minum. Proses pengolahan air minum pada DAMIU A belum bisa dikatakan baik, mungkin ada bebrapa faktor yang menyebabkan kualitas air minum yang dihasilkan tidak memenuhi persyaratan yang sudah di tentukan. Perlu adanya pengawasan serta pemeriksaan alat pengolahan yang digunakan guna memperbaiki kualitas air minum yang dihasilkan.

\section{DAMIU B}

Kondisi lantai pada DAMIU B sudah kedap air, permukaan rata, tidak licin, mudah dibersihkan dan kemiringan lantai cukup landai. Keadaan dinding sudah kedap air, permukaan rata, tidak retak, serta memiliki warna yang terang dan cerah. Langit-langit pada DAMIU B tidak memiliki atap anti tikus jadi sangat memungkinkan untuk adanya tikus dan keadaan atap rumah yang kotor serta tidak mudah untuk dibersihkan. Kondisi pencahayaan pada DAMIU B cukup terang untuk bekerja, tidak menyilaukan dan tersebar secara merata, sehingga pekerjaan tidak terganggu akibat pencahayaan yang kurang atau berlebih. Ventilasi pada DAMIU B sudah cukup memadai sehingga pertukaran udara berjalan dengan lancar serta kelembaban udara yang dihasilkan dapat mendukung kenyamanan dalam meakukan pekerjaan/ aktivitas. DAMIU B sudah memiliki akses kamar mandi dan jamban bagi pekerja nya dan saluran pembuangan air limbah pada DAMIU B sudah tertutup. DAMIU B belum memiliki tempat sampah yang tertutup dan belum memiliki tempat cuci tangan untuk operator yang bekerja. Kondisi pada DAMIU B sangat memungkinkan adanya dari tikus, lalat dan kecoa jika dilihat dari bangunan dari DAMIU B itu sendiri, sehingga dapat dikatakan DAMIU B belum terbebas dari tikus, lalat dan kecoa.

Mikrofilter dan peralatan desinfeksi masih dalam masa pakai/ tidak kadaluarsa, serta memiliki lebih dari satu mikro filter dengan ukuran berjenjang. DAMIU B sudah terdapat peralatan sterilisasi berupa ultra violet yang biasa digunakan untuk proses produksi. Penggunaan sinar ultra violet dilakukan pergantian jika lampu sudah mulai menyala redup, biasanya 1 tahun sekali, tergantung pada penggunaan ultra violet.

Penjamah/ operator pada DAMIU B dalam kondisi sehat, bebas penyakit menular, tidak menjadi pembawa kuman penyakit, menggunakan pakaian kerja yang bersih dan rapi. Penanggung jawab/ operator DAMIU B belum memiliki sertifikat pelatihan higiene sanitasi depot air minum dan belum adanya pemeriksaan kesehatan secara berkala untuk operator yang bekerja pada DAMIU B tersebut.

Bahan baku atau air baku yang digunakan belum memenuhi persyaratan fisik, mikrobiologi dan kimia standar serta kualitas air minum yang dihasilkan belum memenuhi persyaratan sesuai Permenkes RI Nomor 492/MENKES/Per/ VI/2010 tentang persyaratan kualitas air minum. Proses pengolahan air minum pada DAMIU B belum bisa dikatakan baik, mungkin ada bebrapa faktor yang menyebabkan kualitas air minum yang dihasilkan tidak memenuhi persyaratan yang sudah ditentukan. Perlu adanya pengawasan serta pemeriksaan alat pengolahan yang digunakan guna memperbaiki kualitas air minum yang dihasilkan.

\section{DAMIU C}

Kondisi lantai pada DAMIU C sudah kedap air, permukaan rata, tidak licin, mudah dibersihkan dan kemiringan lantai cukup landai. Keadaan dinding sudah kedap air, permukaan rata, tidak retak, serta memiliki warna yang terang dan cerah. Langit-langit pada DAMIU C tidak memiliki atap anti tikus jadi sangat memungkinkan untuk adanya tikus dan keadaan atap rumah yang kotor serta tidak mudah untuk dibersihkan. Kondisi pencahayaan pada DAMIU $\mathrm{C}$ cukup terang untuk bekerja, tidak menyilaukan dan tersebar secara merata. Sehingga pekerjaan tidak terganggu akibat pencahayaan yang kurang atau berlebih. Ventilasi pada DAMIU C sudah cukup memadai sehingga pertukaran udara berjalan dengan lancar serta kelembaban udara yang dihasilkan dapat mendukung kenyamanan dalam meakukan pekerjaan/ aktivitas. DAMIU C sudah memiliki akses kamar mandi dan jamban bagi pekerja nya dan untuk saluran pembuangan air limbah pada DAMIU C sudah tertutup. DAMIU C belum memiliki tempat sampah yang tertutup, sedangkan DAMIU C sudah memiliki tempat cuci tangan untuk operator yang bekerja. 
Kondisi pada DAMIU C sangat memungkinkan adanya dari tikus, lalat dan kecoa jika dilihat dari bangunan dari DAMIU C itu sendiri, sehingga dapat dikatakan DAMIU C belum terbebas dari tikus, lalat dan kecoa.

Mikrofilter dan peralatan desinfeksi masih dalam masa pakai/ tidak kadaluarsa, serta memiliki lebih dari satu mikro filter dengan ukuran berjenjang. DAMIU C sudah terdapat peralatan sterilisasi berupa ultra violet yang biasa digunakan untuk proses produksi. Penggunaan sinar ultra violet dilakukan pergantian jika lampu sudah mulai menyala redup, biasanya 1 tahun sekali, tergantung pada penggunaan ultra violet.

Penjamah/ operator pada DAMIU C dalam kondisi sehat, bebas penyakit menular, tidak menjadi pembawa kuman penyakit, menggunakan pakaian kerja yang bersih dan rapi. Penanggung jawab DAMIU C sudah memiliki sertifikat pelatihan higiene sanitasi depot air minum dan belum adanya pemeriksaan kesehatan secara berkala untuk operator yang bekerja pada DAMIU C tersebut.

Bahan baku atau air baku yang digunakan belum memenuhi persyaratan fisik, mikrobiologi dan kimia standar namun kualitas air minum yang dihasilkan sudah memenuhi persyaratan sesuai Permenkes RI Nomor 492/MENKES/Per/VI/2010 tentang persyaratan kualitas air minum. Maka hal ini dapat dikatakan proses pengolahan yang dilakukan oleh DAMIU C sudah baik.

\section{DAMIU D}

Kondisi lantai pada DAMIU D sudah kedap air, permukaan rata, tidak licin, mudah dibersihkan dan kemiringan lantai cukup landai. Keadaan dinding sudah kedap air, permukaan rata, tidak retak, serta memiliki warna yang terang dan cerah. Kondisi langit-langit kuat, anti tikus, mudah dibersihkan, berwarna terang dan mempunyai tinggi yang cukup. Kondisi pencahayaan pada DAMIU D cukup terang untuk bekerja, tidak menyilaukan dan tersebar secara merata, sehingga pekerjaan tidak terganggu akibat pencahayaan yang kurang atau berlebih. Ventilasi pada DAMIU D sudah cukup memadai sehingga pertukaran udara berjalan dengan lancar serta kelembaban udara yang dihasilkan dapat mendukung kenyamanan dalam meakukan pekerjaan/ aktivitas. DAMIU D sudah memiliki akses kamar mandi dan jamban bagi pekerja nya, dan saluran pembuangan air limbah pada DAMIU $\mathrm{D}$ belum tertutup. DAMIU D belum memiliki tempat sampah yang tertutup namun sudah memiliki tempat cuci tangan untuk operator yang bekerja. Kondisi pada DAMIU D sudah terbebas dari tkus, lalat, dan kecoa karena sewaktu inspeksi tidak di temukan vektor tersebut dan faktor risiko adanya vektor tersebut pada DAMIU D dapat dikatakan rendah.
Mikrofilter dan peralatan desinfeksi masih dalam masa pakai/ tidak kadaluarsa, serta memiliki lebih dari satu mikro filter dengan ukuran berjenjang. DAMIU D sudah terdapat peralatan sterilisasi berupa ultra violet yang biasa digunakan untuk proses produksi. Penggunaan sinar ultra violet dilakukan pergantian jika lampu sudah mulai menyala redup, biasanya 1 tahun sekali, tergantung pada penggunaan ultra violet.

Penjamah/ operator pada DAMIU D dalam kondisi sehat, bebas penyakit menular, tidak menjadi pembawa kuman penyakit, menggunakan pakaian kerja yang bersih dan rapi. Operator yang bekerja belum berperilaku higiene dan sanitasi setiap melayani konsumen serta operator/ penanggung jawab DAMIU D belum mendapatkan sertifikat telah mengikuti pelatihhan higiene sanitasi depot air minum dan belum adanya pemeriksaan kesehatan secara berkala untuk operator yang bekerja pada DAMIU D tersebut.

Bahan baku atau air baku yang digunakan belum memenuhi persyaratan fisik, mikrobiologi dan kimia standar namun kualitas air minum yang dihasilkan sudah memenuhi persyaratan sesuai Permenkes RI Nomor 492/MENKES/Per/VI/2010 tentang persyaratan kualitas air minum. Maka hal ini dapat dikatakan proses pengolahan yang dilakukan oleh DAMIU D sudah baik

\section{DAMIU E}

Kondisi lantai pada DAMIU E sudah kedap air, permukaan rata, tidak licin, mudah dibersihkan dan kemiringan lantai cukup landai. Keadaan dinding sudah kedap air, permukaan rata, tidak retak, serta memiliki warna yang terang dan cerah. Kondisi langit-langit kuat, anti tikus, mudah dibersihkan, berwarna terang dan mempunyai tinggi yang cukup. Kondisi pencahayaan pada DAMIU E cukup terang untuk bekerja, tidak menyilaukan dan tersebar secara merata dan tidak mengganggu. Ventilasi pada DAMIU E sudah cukup memadai sehingga pertukaran udara berjalan dengan lancar serta kelembaban udara yang dihasilkan dapat mendukung kenyamanan dalam meakukan pekerjaan/ aktivitas. DAMIU E sudah memiliki akses kamar mandi dan jamban bagi pekerja nya serta saluran pembuangan air limbah pada DAMIU E belum tertutup. DAMIU E belum memiliki tempat sampah yang tertutup dan belum memiliki tempat cuci tangan untuk operator yang bekerja. Kondisi pada DAMIU E masih memungkinkan adanya dari tikus, lalat dan kecoa jika dilihat lokasi dari DAMIU E itu sendiri, sehingga dapat dikatakan DAMIU E belum terbebas dari tikus, lalat dan kecoa.

Mikrofilter dan peralatan desinfeksi masih dalam masa pakai/ tidak kadaluarsa, serta memiliki lebih dari satu mikro filter dengan 
ukuran berjenjang. DAMIU E sudah terdapat peralatan sterilisasi berupa ultra violet yang biasa digunakan untuk proses produksi. Penggunaan sinar ultra violet dilakukan pergantian jika lampu sudah mulai menyala redup, biasanya 1 tahun sekali, tergantung pada penggunaan ultra violet.

Penjamah/ operator pada DAMIU E dalam kondisi sehat, bebas penyakit menular, tidak menjadi pembawa kuman penyakit, menggunakan pakaian kerja yang bersih dan rapi. Operator yang bekerja belum berperilaku higiene dan sanitasi setiap melayani konsumen serta operator/ penanggung jawab DAMIU E belum mendapatkan sertifikat pelatihan higiene sanitasi depot air minum dan belum adanya pemeriksaan kesehatan secara berkala untuk operator yang bekerja pada DAMIU E tersebut.

Bahan baku atau air baku yang digunakan belum memenuhi persyaratan fisik, mikrobiologi dan kimia standar dan kualitas air minum yang dihasilkan juga belum memenuhi persyaratan sesuai Permenkes RI Nomor 492/MENKES/Per/ VI/2010 tentang persyaratan kualitas air minum. Maka dapat dikatakan proses pengolahan air minum pada DAMIU E belum bisa dikatakan baik, mungkin ada bebrapa faktor yang menyebabkan kualitas air minum yang dihasilkan tidak memenuhi persyaratan yang sudah di tentukan. Perlu adanya pengawasan serta pemeriksaan alat pengolahan yang digunakan guna memperbaiki kualitas air minum yang dihasilkan.

\section{DAMIU F}

Kondisi lantai pada DAMIU F sudah kedap air, permukaan rata, tidak licin, mudah dibersihkan dan kemiringan lantai cukup landai. Keadaan dinding sudah kedap air, permukaan rata, tidak retak, serta memiliki warna yang terang dan cerah. Kondisi langit-langit kuat, anti tikus, mudah dibersihkan, berwarna terang dan mempunyai tinggi yang cukup. Kondisi pencahayaan pada DAMIU F cukup terang untuk bekerja, tidak menyilaukan dan tersebar secara merata, sehingga pekerjaan tidak terganggu akibat pencahayaan yang kurang atau berlebih.Ventilasi pada DAMIU F sudah cukup memadai sehingga pertukaran udara berjalan dengan lancar serta kelembaban udara yang dihasilkan dapat mendukung kenyamanan dalam meakukan pekerjaan/ aktivitas. DAMIU F sudah memiliki akses kamar mandi dan jamban bagi pekerja nya, namun saluran pembuangan air limbah pada DAMIU $F$ belum tertutup.DAMIU $F$ belum memiliki tempat sampah yang tertutup dan juga belum memiliki tempat cuci tangan untuk operator yang bekerja. Kondisi pada DAMIU F sudah terbebas dari tkus, lalat, dan kecoa karena sewaktu inspeksi tidak di temukan vektor tersebut dan faktor risiko adanya vektor tersebut pada DAMIU F dapat dikatakan rendah.

Mikrofilter dan peralatan desinfeksi masih dalam masa pakai/ tidak kadaluarsa, serta memiliki lebih dari satu mikro filter dengan ukuran berjenjang. DAMIU $F$ sudah terdapat peralatan sterilisasi berupa ultra violet yang biasa digunakan untuk proses produksi. Penggunaan sinar ultra violet dilakukan pergantian jika lampu sudah mulai menyala redup, biasanya 1 tahun sekali, tergantung pada penggunaan ultra violet.

Penjamah/ operator pada DAMIU F dalam kondisi sehat, bebas penyakit menular, tidak menjadi pembawa kuman penyakit, menggunakan pakaian kerja yang bersih dan rapi. Namun untuk operator yang bekerja belum berperilaku higiene dan sanitasi setiap melayani konsumen serta operator/ penanggung jawab DAMIU F belum mendapatkan sertifikat telah mengikuti pelatihan higiene sanitasi depot air minum dan belum adanya pemeriksaan kesehatan secara berkala untuk operator yang bekerja pada DAMIU F tersebut.

Bahan baku atau air baku yang digunakan belum memenuhi persyaratan fisik, mikrobiologi dan kimia standar namun kualitas air minum yang dihasilkan sudah memenuhi persyaratan sesuai Permenkes RI Nomor 492/MENKES/Per/VI/2010 tentang persyaratan kualitas air minum. Makah al ini dapat dikatakan proses pengolahan yang dilakukan oleh DAMIU F sudah baik.

\section{DAMIU G}

Kondisi lantai pada DAMIU G sudah kedap air, permukaan rata, tidak licin, mudah dibersihkan dan kemiringan lantai cukup landai. Keadaan dinding sudah kedap air, permukaan rata, tidak retak, serta memiliki warna yang terang dan cerah. Kondisi langit-langit kuat, anti tikus, mudah dibersihkan, berwarna terang dan mempunyai tinggi yang cukup. Pencahayaan pada DAMIU G cukup terang untuk bekerja, tidak menyilaukan dan tersebar secara merata. Sehingga pekerjaan tidak terganggu akibat pencahayaan yang kurang atau berlebih. Ventilasi pada DAMIU G sudah cukup memadai sehingga pertukaran udara berjalan dengan lancar serta kelembaban udara yang dihasilkan dapat mendukung kenyamanan dalam meakukan pekerjaan/ aktivitas. DAMIU G sudah memiliki akses kamar mandi dan jamban bagi pekerja nya, namun saluran pembuangan air limbah pada DAMIU $G$ belum tertutup. DAMIU $G$ belum memiliki tempat sampah yang tertutup dan juga belum memiliki tempat cuci tangan untuk operator yang bekerja. Kondisi pada DAMIU G sudah terbebas dari tkus, lalat, dan kecoa karena sewaktu inspeksi tidak di temukan vektor tersebut dan faktor risiko adanya vektor tersebut pada DAMIU F dapat dikatakan rendah. 
Mikrofilter dan peralatan desinfeksi masih dalam masa pakai/ tidak kadaluarsa, serta memiliki lebih dari satu mikro filter dengan ukuran berjenjang. DAMIU G sudah terdapat peralatan sterilisasi berupa ultra violet yang biasa digunakan untuk proses produksi. Penggunaan sinar ultra violet dilakukan pergantian jika lampu sudah mulai menyala redup, biasanya 1 tahun sekali, tergantung pada penggunaan ultra violet.

Penjamah/ operator pada DAMIU G dalam kondisi sehat, bebas penyakit menular, tidak menjadi pembawa kuman penyakit, menggunakan pakaian kerja yang bersih dan rapi. Operator yang bekerja belum berperilaku higiene dan sanitasi setiap melayani konsumen serta operator/ penanggung jawab DAMIU G belum mendapatkan sertifikat telah mengikuti pelatihan higiene sanitasi depot air minum dan belum adanya pemeriksaan kesehatan secara berkala untuk operator yang bekerja pada DAMIU G tersebut.

Bahan baku atau air baku yang digunakan belum memenuhi persyaratan fisik, mikrobiologi dan kimia standar namun kualitas air minum yang dihasilkan sudah memenuhi persyaratan sesuai Permenkes RI Nomor 492/MENKES/Per/VI/2010 tentang persyaratan kualitas air minum. Maka hal ini dapat dikatakan proses pengolahan yang dilakukan oleh DAMIU G sudah baik.

\section{DAMIU H}

Kondisi lantai pada DAMIU H sudah kedap air, permukaan rata, tidak licin, mudah dibersihkan dan kemiringan lantai cukup landai. Keadaan dinding sudah kedap air, permukaan rata, tidak retak, serta memiliki warna yang terang dan cerah. Kondisi langit-langit kuat, anti tikus, mudah dibersihkan, berwarna terang dan mempunyai tinggi yang cukup. Pencahayaan pada DAMIU $\mathrm{H}$ cukup terang untuk bekerja, tidak menyilaukan dan tersebar secara merata, sehingga pekerjaan tidak terganggu akibat pencahayaan yang kurang atau berlebih.Ventilasi pada DAMIU $\mathrm{H}$ sudah cukup memadai sehingga pertukaran udara berjalan dengan lancar serta kelembaban udara yang dihasilkan dapat mendukung kenyamanan dalam meakukan pekerjaan/ aktivitas. DAMIU H sudah memiliki akses kamar mandi dan jamban bagi pekerja nya, namun saluran pembuangan air limbah pada DAMIU $\mathrm{H}$ belum tertutup. DAMIU $\mathrm{H}$ belum memiliki tempat sampah yang tertutup dan juga belum memiliki tempat cuci tangan untuk operator yang bekerja. Kondisi pada DAMIU H sudah terbebas dari tkus, lalat, dan kecoa karena sewaktu inspeksi tidak di temukan vektor tersebut dan faktor resiko adanya vektor tersebut pada DAMIU $\mathrm{H}$ dapat dikatakan rendah.

Mikrofilter dan peralatan desinfeksi masih dalam masa pakai/ tidak kadaluarsa, serta memiliki lebih dari satu mikro filter dengan ukuran berjenjang. DAMIU $\mathrm{H}$ sudah terdapat peralatan sterilisasi berupa ultra violet yang biasa digunakan untuk proses produksi. Penggunaan sinar ultra violet dilakukan pergantian jika lampu sudah mulai menyala redup, biasanya 1 tahun sekali. Tergantung pada penggunaan ultra violet.

Penjamah/ operator pada DAMIU H dalam kondisi sehat, bebas penyakit menular, tidak menjadi pembawa kuman penyakit, menggunakan pakaian kerja yang bersih dan rapi. Operator yang bekerja sudah berperilaku higiene dan sanitasi setiap melayani konsumen yaitu salah satunya dengan mencuci tangan menggunakan sabun sebelum melayani konsumen namun operator/ penanggung jawab DAMIU $\mathrm{H}$ belum mendapatkan sertifikat telah mengikuti pelatihan higiene sanitasi depot air minum dan belum adanya pemeriksaan kesehatan secara berkala untuk operator yang bekerja pada DAMIU $\mathrm{H}$ tersebut.

Bahan baku atau air baku yang digunakan belum memenuhi persyaratan fisik, mikrobiologi dan kimia standar namun kualitas air minum yang dihasilkan sudah memenuhi persyaratan sesuai Permenkes RI Nomor 492/MENKES/Per/VI/2010 tentang persyaratan kualitas air minum. Maka hal ini dapat dikatakan proses pengolahan yang dilakukan oleh DAMIU H sudah baik.

\section{DAMIU I}

Kondisi lantai pada DAMIU I sudah kedap air, permukaan rata, tidak licin, mudah dibersihkan dan kemiringan lantai cukup landai. Keadaan dinding sudah kedap air, permukaan rata, tidak retak, serta memiliki warna yang terang dan cerah. Kondisi langit-langit belum kuat, belum anti tikus, tidak mudah dibersihkan. Kondisi pencahayaan pada DAMIU I cukup terang untuk bekerja, tidak menyilaukan dan tersebar merata. Ventilasi pada DAMIU I sudah cukup memadai sehingga pertukaran udara berjalan dengan lancar serta kelembaban udara yang dihasilkan dapat mendukung kenyamanan dalam meakukan pekerjaan/ aktivitas. DAMIU I sudah memiliki akses kamar mandi dan jamban bagi pekerja nya, namun saluran pembuangan air limbah pada DAMIU I belum tertutup. DAMIU I belum memiliki tempat sampah yang tertutup dan juga belum memiliki tempat cuci tangan untuk operator yang bekerja. Kondisi pada DAMIU I sudah terbebas dari tkus, lalat, dan kecoa karena sewaktu inspeksi tidak di temukan vektor tersebut dan faktor risiko adanya vektor tersebut pada DAMIU F dapat dikatakan rendah.

Mikrofilter dan peralatan desinfeksi masih dalam masa pakai/ tidak kadaluarsa, serta memiliki lebih dari satu mikro filter dengan ukuran berjenjang. DAMIU I sudah terdapat peralatan sterilisasi berupa ultra violet yang biasa 
digunakan untuk proses produksi. Penggunaan sinar ultra violet dilakukan pergantian jika lampu sudah mulai menyala redup, biasanya 1 tahun sekali, tergantung pada penggunaan ultra violet.

Penjamah/ operator pada DAMIU I dalam kondisi sehat, bebas penyakit menular, tidak menjadi pembawa kuman penyakit, menggunakan pakaian kerja yang bersih dan rapi. Operator yang bekerja belum berperilaku higiene dan sanitasi setiap melayani konsumen serta operator/ penanggung jawab DAMIU I belum mendapatkan sertifikat telah mengikuti pelatihan higiene sanitasi depot air minum dan belum adanya pemeriksaan kesehatan secara berkala untuk operator yang bekerja pada DAMIU I tersebut.

Bahan baku atau air baku yang digunakan belum memenuhi persyaratan fisik, mikrobiologi dan kimia standar namun kualitas air minum yang dihasilkan sudah memenuhi persyaratan sesuai Permenkes RI Nomor 492/MENKES/Per/VI/2010 tentang persyaratan kualitas air minum. Maka hal ini dapat dikatakan proses pengolahan yang dilakukan oleh DAMIU I sudah baik.

Tabel 6. Kualitas Bakteri Coliform Air Minum Isi Ulang pada DAMIU

\begin{tabular}{|c|c|c|c|}
\hline No. & $\begin{array}{c}\text { Nama } \\
\text { DAMIU }\end{array}$ & $\begin{array}{c}\text { Jumlah MPN } \\
\text { Colifrm/ } 100 \mathrm{ml}\end{array}$ & Ket \\
\hline 1. & DAMIU A & 2,2 & TMS \\
\hline 2. & DAMIU B & 8,8 & TMS \\
\hline 3. & DAMIU C & 0 & MS \\
\hline 4. & DAMIU D & 0 & MS \\
\hline 5. & DAMIU E & 15 & TMS \\
\hline 6. & DAMIU F & 0 & MS \\
\hline 7. & DAMIU G & 0 & MS \\
\hline 8. & DAMIU H & 0 & MS \\
\hline 9. & DAMIU I & 0 & MS \\
\hline
\end{tabular}

DAMIU yang diteliti di wilayah kerja Puskesmas 1 Purwokerto Timur Kabupaten Banyumas, jika dibandingkan dengan Peraturan Menteri Kesehatan Nomor 492 tahun 2010 tentang Persyaratan Kualitas Air Minum dengan batas maksimal cemaran MPN Coliform adalah 0/100 $\mathrm{ml}$ sampel air. Bahwa DAMIU yang memenuhi syarat yaitu DAMIU C, D, F, G, H dan I yaitu 0/100 ml sampel air. Sedangkan yang tidak memenuhi syarat yaitu pada DAMIU A dengan jumlah cemaran MPN Coliform 2,2/100 ml sampel air, DAMIU B jumlah cemaran MPN Coliform 8,8/100 $\mathrm{ml}$ sampel air, DAMIU E jumlah cemaran MPN Coliform 15/100 ml sampel air.

\section{Simpulan dan Saran Simpulan}

Berdasarkan penelitian yang telah dilakukan pada 9 DAMIU di wilayah kerja Puskesmas 1 Purwokerto Timur Kabupaten Banyumas Tahun 2018 dapat disimpulkan sebagai berikut:
DAMIU yang ada di wilayah kerja Puskesmas 1 Purwokerto Timur Kabupaten Banyumas pada tahun 2018 berjumlah 9 DAMIU. Terdapat 3 DAMIU menggunakan PDAM, 3 DAMIU menggunakan sumur bor dan 3 DAMIU menggunakan sumur gali sebagai bahan baku air minum. Kualitas Air bahan baku yang diperiksa dari 9 DAMIU yang mana, 6 DAMIU tidak memenuhi syarat dan 3 DAMIU memenuhi syarat kualitas fisik apabila dibandingkan dengan Peraturan Menteri Kesehatan Republik Indonesia No. 416 Tahun 1990 tentang Syarat-syarat dan Pengawasan Kualitas Air.

DAMIU yang ada di wilayah kerja Puskesmas 1 Purwokerto Timur Kabupaten Banyumas pada tahun 2018 berjumlah 9 DAMIU. Seluruh jenis pengolahan dari 9 DAMIU menggunakan UV.

DAMIU yang ada di wilayah kerja Puskesmas 1 Purwokerto Tmur Kabupaten Banyumas berjumlah 9 DAMIU terdapat 3 DAMIU yang tidak memenuhi syarat sanitasi DAMIU dan 6 DAMIU yang memenuhi syarat sanitasi DAMIU.

Berdasarkan Peraturan Menteri Kesehatan Republik Indonesia No. 492 Tahun 2010 tentang Persyaratan Kualitas Air Minum, 9 DAMIU yang ada di wilayah kerja Puskesmas 1 Purwokerto Kabupaten Banyumas terdapat 6 DAMIU yang memenuhi syarat dan 3 DAMIU yang tidak memenuhi syarat.

\section{Saran}

Saran yang dapat diberikan bagi Dinas Kesehatan Kabupaten Banyumas yaitu sebaiknya dilakukan pemantauan dan pengawasan minimal 6 bulan sekali terhadap DAMIU untuk menjamin kualitas air minum yang diproduksi.

Saran yang dapat diberikan bagi petugas Puskesmas yaitu perlu adanya peningkatan pemantauan dan pengambilan sampel air minum isi ulang secara rutin minimal 3 bulan sekali. Perlu adanya pelatihan rutin kepada pengusaha atau tenaga kerja DAMIU tentang kegiatan pengolahan air minum yang benar dan sesuai dengan baku mutu. Membantu pengusaha DAMIU untuk melakukan pembuatan Sertifikat Laik Hygiene Sanitasi DAMIU.

Saran yang dapat diberikan bagi pengusaha DAMIU yaitu kepada pengelola atau pemilik DAMIU yang belum memiliki Sertifikat Laik Higiene Sanitasi DAMIU hendaknya mengajukan kepada Dinas Kesehatan Kabupaten Banyumas untuk pembuatan Sertifikat Laik Higiene Sanitasi DAMIU. Pemilik DAMIU sebaiknya selalu mengganti lampu UV yang pemakaiannya sudah melebihi 9.000 jam dan menyesuaikan debit air yang keluar dari alat pengolahan dengan kapasitas UV agar hasil air olahan memenuhi syarat kualitas bakteriologis. Memperbaiki sanitasi sarana sumber air baku DAMIU yang belum memenuhi syarat agar mengurangi pencemaran yang dapat terjadi terhadap air bahan baku air 
minum. Memperbaiki dan memelihara sanitasi tempat penjualan dan tempat pengolahan air minum agar memenuhi syarat sanitasi dan mencegah terjadinya pencemaran terhadap air bahan baku dan air minum yang sudah diolah. Operator sebaiknya menggunakan pakaian kerja yang bersih dan rapi

Serta pada saat bekerja tidak sambil merokok. Operator sebaiknya selalu mencuci tangan menggunakan sabun dengan air yang mengalir.

Saran yang dapat diberikan bagi masyarakat yaitu sebaiknya berhati-hati dalam memilih Depot Air Minum Isi Ulang (DAMIU) untuk memenuhi kebutuhan air minum sehari-hari dan perlu memperhatikan beberapa hal misalnya dengan melihat kondisi sanitasi depot air minum, perilaku tenaga pengolah air minum dan kepemilikan Sertifikat Laik Higiene yang masih berlaku.

\section{Daftar Pustaka}

Dewi Mustikaningtyas. 2014. "Kajian Kualitas Bakteriologis Air Minum Isi Ulang di Kabupaten Blora" http://journal.unnes. ac.id/sju/index.php/unnesJLifeSci. diakses pada tanggal 17 Febuari 2016

Dwi Lestari. 2014. Sanitasi dan Kualitas Bakteriologis Air Minum pada Depot Air Minum Isi Ulang (DAMIU) di Kecamatan Kalimanah Kabupaten Purbalingga Tahun 2014. Purwoketo: Poltekkes Kemenkes Semarang Jurusan Kesehatan Lingkungan

Herwanti. 2013. Studi Kualitas Bakteriologis Depot Air Minum Isi Ulang (DAMIU) di wilayah Kerja Puskesmas Purwokerto Selatan Kabupaten Banyumas Tahun 2013. Purwokerto: Poltekkes Kemenkes Semarang Jurusan Kesehatan Lingkungan

Muchlisin Riadi. 2014. "Depot Air Minum Isi Ulang" .http://www.kajianpustaka.com/ 2014/04/depot-air-minum-isi-

ulang.html? $m=1$.. diakses pada tanggal 2 April 2014
Peraturan Menteri Kesehatan No.43 Tahun 2014 tentang Higiene Sanitasi Depot Air Minum

Peraturan Menteri Kesehatan Republik Indonesia Nomor 492/Menkes/Per/IV/2010 tentang Persyaratan Kualitas Air Minum

Peraturan Menteri Kesehatan RI No.32 tahun 2017 tentang Standar Baku Mutu Kesehatan Lingkungan dan Persyaratan Kesehatan Air untuk Keperluan Higiene Sanitasi, Kolam Renang, Solus Per Aqua, dan Pemandian Umum

Seri Asnawanti Munthe, " Hubungan Kondisi Lokasi dan Alat Perlengkapan pada Depot Air Minu Isi Ulang dengan Kualitas Bakteriologis di Kecamatan Medan Helvetia Tahun 2012"

Siti Nurhikmah. 2017. Kualitas Mikrobiologis Air Minum Isi Ulang pada Depot Air Minum Isi Ulang di Wilayah Kerja Puskesmas Kebasen Kabupaten Banyumas Tahun 2017. Purwokerto: Poltekkes Kemenkes Semarang Jurusan Kesehatan Lingkungan

Totok Sutrisno, dkk, 2010, Teknologi Penyediaan Air Bersih, Jakarta : PT Rineka Cipta

Tri Cahyono, 2018, Panduan Penulisan Tugas Akhir, Purwokerto: Kementerian Kesehatan Republik Indonesia Politeknik Kesehatan Kemenkes Semarang Jurusan Kesehatan Lingkungan Purwokerto

Wilyatri S R. 2016. Kualitas Mikrobiologis Air Minum Isi Ulang Botol Berkran yang dijual pada Warung di Kecamatan Baturraden tahun 2016, Purwokerto: Poltekkes Kemenkes Semarang Jurusan Kesehatan Lingkungan 